\title{
6-Phosphofructokinase, Muscle Type
}

National Cancer Institute

\section{Source}

National Cancer Institute. 6-Phosphofructokinase, Muscle Type. NCI Thesaurus. Code C104791.

6-phosphofructokinase, muscle type (780 aa, $\sim 85 \mathrm{kDa}$ ) is encoded by the human PFKM gene. This protein is involved in the mediation of muscle cell glycolysis. 